\title{
ANALISIS PENGARUH NILAI TUKAR RUPIAH, TINGKAT SUKU BUNGA SBI (BI RATE) DAN HARGA EMAS DUNIA TERHADAP INDEKS LQ45 DI BURSA EFEK INDONESIA
}

\author{
Miftahul Jannah \\ Nurfauziah \\ Program Studi Manajemen, Fakultas Ekonomi UII \\ Email: mithamiftahul30@gmail.com
}

Submitted: May 12, 2017; Reviewed: May 14, 2017; Accepted: Oct 8, 2017

\begin{abstract}
The purpose of this paper is to investigate the impact of macroeconomic on Index LQ45 in Indonesian Stock Exchange (BEI). Used data were daily report from 2011 until 2015. This study used linear regression analysis method to see the effect of exchange rate, interest rate (BI rate) and gold price on Index LQ45. Based on the results of this study, exchange rate and gold price have a positive and significant effect on Index LQ45, while interest rate (BI rate) has a negative and significant effect.
\end{abstract}

\section{Keywords: Index LQ45, Exchange rate, SBI Interest Rate (BI rate), Gold Price}

\section{PENDAHULUAN}

Pasar modal memiliki fungsi yaitu sebagai sarana bagi perusahaan untuk mendapatkan dana dari pemodal untuk menjalankan usahanya dan sebagai sarana investasi bagi investor. Pasar modal di Indonesia (BEI) memiliki banyak indeks harga saham. Indeks adalah salah satu petunjuk bagi investor untuk melakukan investasi di pasar modal karena mencerminkan pergerakan saham anggotanya. Salah satunya yaitu Indeks LQ45. Indeks LQ45 terdiri dari 45 saham yang telah memenuhi kriteria baik yaitu dengan kapitalisasi pasar dan tingkat likuiditas yang tinggi, dimana daftar emiten yang masuk dalam indeks ini akan disesuaikan setiap 6 bulan sekali.

Pasar modal erat kaitannya dengan keadaan makro ekonomi. Kondisi makro ekonomi adalah kondisi yang berasal dari eksternal perusahaan, seperti tingkat suku bunga, nilai tukar rupiah dan harga emas dunia. Fluktuasi nilai tukar rupiah menjadi perhatian bagi investor karena ketika perusahaan memiliki hutang dalam bentuk dollar sedangkan barang yang dihasilkan dijual di dalam negeri maka emiten akan mendapat dampak yang negatif. Hal ini dikarenakan ketika nilai tukar rupiah terdepresiasi, maka dapat meningkatkan biaya yang dikeluarkan oleh perusahaan untuk membayar hutang dan kemudian berdampak pada berkurangnya profit dari perusahaan. Dengan demikian, investor cenderung menunjukkan sentimen negatif di pasar modal. Mereka cenderung menjual saham yang dimiliki, maka dapat mendorong penurunan harga saham yang berdampak pada turunnya indeks harga saham. Pada penelitian ini digunakan nilai tukar rupiah terhadap dollar Amerika Serikat. Kemudian tingkat suku bunga SBI (BI rate), merupakan suku bunga yang digunakan oleh Bank Indonesia selaku bank central sebagai alat pengendali moneter. Menurut Sudirman (2011) kebijakan moneter dengan menambah jumlah uang yang beredar akan menyebabkan turunnya suku bunga sehingga akan meningkat investasi dan kemudian meningkatkan produksi nasional. Dengan rendahnya tingkat suku bunga SBI (BI rate) mendorong investor untuk berinvestasi pada saham dibanding menyimpan uangnya di bank dalam bentuk tabungan karena lebih menguntungkan. Dapat diartikan bahwa tingkat suku bunga berpengaruh negatif terhadap indeks harga saham. Faktor lain yang mempengaruhi pasar modal adalah emas. Emas merupakan salah satu instrumen investasi yang banyak diminati. Hal ini dikarenakan nilainya yang cenderung 
stabil, risiko yang rendah dan memiliki likuiditas yang tinggi.

Menurut penelitian terdahulu yang dilakukan oleh Langi dkk (2014), menyatakan bahwa tingkat suku bunga berpengaruh positif signifikan terhadap tingkat inflasi di Indonesia, sedangkan jumlah uang beredar dan tingkat kurs berpengaruh positif tidak signifikan terhadap inflasi di Indonesia. Penelitian ini dilakukan pada inflasi di Indonesia pada periode tahun 2005 2013.

Menurut Purnomo (2013) dalam hasil penelitian yang dilakukan terhadap perusahaan property pada tahun 2009-2012, tingkat suku bunga berpengaruh signifikan terhadap return saham sedangkan nilai tukar rupiah dan inflasi tidak berpengaruh terhadap return saham.

Hal yang menjadi keterbaharuan dan pembeda dengan penelitian terdahulu adalah karena peneliti mencoba untuk mengkolaborasikan antara 3 variabel makro ekonomi yaitu nilai tukar rupiah terhadap dollar Amerika Serikat, tingkat suku bunga SBI (BI rate) dan harga emas dunia yang kemudian akan diuji bagaimana pengaruhnya terhadap Indeks LQ45. Data yang akan digunakan adalah data harian selama 5 tahun pengamatan yaitu pada tahun 2011 sampai dengan 2015 dengan harapan memberi hasil yang lebih akurat

Permasalahan dalam penelitian ini adalah bagaimana pengaruh antara nilai tukar rupiah, tingkat suku bunga SBI (BI rate) dan harga emas dunia terhadap Indeks LQ45 secara parsial. Dengan demikian, tujuan yang ingin dicapai dalam penelitian ini adalah untuk menganalisis adanya pengaruh antara nilai tukar rupiah, tingkat suku bunga SBI (BI rate) dan harga emas dunia terhadap Indeks LQ45. Sedangkan manfaat dari penulisan ini bagi akademisi adalah memberikan informasi mengenai faktor makro ekonomi yang mempengaruh indeks harga saham dengan menggunakan pengambilan data harian sehingga dapat mencakup keseluruhan keadaan yang terjadi. Bagi investor agar penelitian ini dijadikan bahan pertimbangan sebelum berinvestasi dipasar modal. Dan bagi penelitian selanjutnya, penelitian ini dapat dijadikan tambahan referensi mengenai faktor makro ekonomi yang dapat mempengaruhi indeks harga saham.
LANDASAN TEORI, KAJIAN EMPIRIS DAN PENGEMBANGAN HIPOTESIS

Indeks harga saham adalah indikator atau cerminan pergerakan harga saham. Indeks merupakan salah satu pedoman bagi investor untuk melakukan investasi di pasar modal, khususnya saham. Salah satu indeks harga saham yang terdaftar di BEI adalah Indeks LQ45. Indeks LQ45 merupakan indeks saham yang dibentuk oleh Bursa Efek Indonesia yang terdiri dari 45 emiten saham dengan likuiditas yang tinggi dan kapitalisasi pasar yang besar. Indeks ini mampu memberikan gambaran pergerakan saham yang aktif diperdagangkan dan mampu mempengaruhi keadaan pasar saham. Indeks LQ45 juga tidak terlepas dari pengaruh faktor makro ekonomi dalam pergerakannya.

Faktor makro ekonomi merupakan faktor yang berada diluar perusahaan, tetapi mempunyai pengaruh terhadap kenaikan atau penurunan kinerja perusahaan baik secara langsung maupun tidak langsung. Perubahan faktor ekonomi tidak akan dengan segera mempengaruhi kinerja perusahaan, tetapi secara perlahan dalam jangka panjang, Sedangkan harga saham bisa lebih cepat menyesuaikan diri daripada kinerja perusahaan terhadap perubahan variabel-variabel makro ekonomi (Samsul, 2006).

Menurut Samsul (2006) perubahan satu variabel makro ekonomi memiliki dampak yang berbeda terhadap setiap jenis saham, yaitu suatu saham dapat terkena dampak positif sedangkan saham yang lainnya terkena dampak negatif. Misalnya kenaikan kurs US\$ yang tajam terhadap emiten yang memiliki utang dalam dollar sementara produk emiten tersebut dijual secara lokal. Sementara itu, emiten yang berorientasi ekspor akan menerima dampak positif dari kenaikan kurs US\$ tersebut. Ini berarti harga saham emiten yang terkena dampak negatif akan mengalami penurunan di Bursa Efek, sementara emiten yang terkena dampak positif akan meningkat harga sahamnya. Sebagian emiten yang tercatat di Bursa Efek akan terkena dampak negatif dan sebagian lagi terkena dampak positif dari perubahan kurs US\$ yang tajam. Selanjutnya, indeks harga saham gabungan juga akan terkena dampak positif atau negatif tergantung pada kelompok yang dominan dampaknya. Penelitian ini menggunakan nilai tukar rupiah terhadap dollar Amerika Serikat. Ketika terjadi pelemahan nilai tukar rupiah, maka berdampak pada emiten yang memiliki hutang dalam bentuk dollar, yang mengakibatkan 
investor memberikan sentimen negatif sehingga harga saham emiten tersebut menjadi turun dan berdampak pada turunnya indeks harga saham.

Tingkat suku bunga memiliki hubungan yang berlawanan dengan harga saham. Ketika tingkat suku bunga tinggi maka harga saham akan cenderung turun. Hal ini disebabkan karena orang akan lebih memilih menyimpan uangnya di bank dengan bunga yang lebih tinggi karena bank cenderung menaikkan suku bunga simpanan, dibanding menginvestasikan uangnya di pasar modal dengan tingkat keuntungan yang fluktuatif. Sedangkan menurut Sudirman (2011), kebijakan moneter dengan menambah jumlah uang beredar akan menyebabkan turunnya suku bunga sehingga akan meningkatkan investasi dan kemudian meningkatkan produksi nasional. Hal ini terjadi ketika pemerintah ingin mendorong pertumbuhan dari sektor industri dan ekonomi, karena aliran modal untuk perusahaan dapat berjalan dengan lancar. Sehingga, ketika tingkat suku bunga rendah, akan membawa dampak pada kegiatan produksi perusahaan yang bertumbuh pesat dan dapat menghasilkan keuntungan yang meningkat serta mampu menarik minat masyarakat untuk berinvestasi kembali, dengan demikian dapat memberikan dampak positif bagi pasar modal. Harga saham akan meningkat dan berdampak pada kenaikan indeks harga saham.

Emas merupakan salah satu instrumen investasi yang banyak diminati. Hal ini dikarenakan nilainya yang cenderung stabil, risiko yang rendah dan memiliki likuiditas yang tinggi. Dengan kondisi demikian, kenaikan harga emas akan mendorong investor untuk lebih memilih menempatkan dananya untuk membeli emas daripada berinvestasi di pasar modal. Hal ini dikarenakan dengan resiko yang relatif lebih rendah, emas dapat menguntungkan. Ketika banyak investor yang mengalihkan portofolio investasi mereka kedalam bentuk emas, hal ini dapat berakibat turunnya indeks harga saham karena aksi jual yang dilakukan investor. Sehingga emas dapat diartikan memiliki pengaruh negatif terhadap indeks harga saham.

Meskipun perdagangan emas dilakukan diseluruh dunia, namun yang menjadi standar emas dunia adalah harga emas London atau yang dikenal dengan London Gold Fixing. London Gold Fixing dalam penetapan harga emas, ditetapkan dua kali dalam satu hari yaitu pada pukul 10.30 am dan $3.00 \mathrm{pm}$. Penetapan harga pada pukul $03.00 \mathrm{pm}$ dianggap sebagai harga penutupan hari perdagangan dan digunakan sebagai patokan kontrak emas diseluruh dunia.

Bhunia dan Pakira (2014) melakukan penelitian mengenai afiliasi antara tiga variabel keuangan yaitu harga emas, nilai tukar dan Sensex (pasar modal India). Periode penlitian yang diambil dimulai pada tahun 1991 sampai dengan 2013. Hasil penelitian menyatakan bahwa Sensex dipengaruhi oleh nilai tukar dan harga emas. Nilai tukar memiliki pengaruh negatif terhadap indeks harga saham, begitu juga dengan harga emas.

Nordin et al (2014) mengungkapkan bahwa terdapat hubungan yang negatif dan signifikan antara suku bunga terhadap pasar saham. Kemudian harga komoditas salah satunya adalah harga emas yang memiliki hubungan positif dan signifikan terhadap pasar saham. Berbeda halnya dengan harga emas yang memiliki hubungan yang positif, nilai tukar memiliki hubungan yang negatif dan signifikan terhadap pasar saham.

Mojazeb dan Shakerian (2014) meneliti mengenai pengaruh harga minyak dan harga emas dunia terhadap return saham perbankan. Periode yang diambil adalah sekitar tahun 2008 sampai dengan tahun 2012. Hasil penelitian ini menyatakan bahwa harga minyak dunia memberikan pengaruh positif yang signifikan terhadap return saham, sedangkan harga emas memiliki dampak negatif yang signifikan terhadap return saham dari perbankan.

Surbakti et al (2016) dalam penelitiannya menyatakan bahwa nilai tukar berpengaruh positif dan signifikan terhadap volatilitas return IHSG. Sedangkan untuk harga emas tidak berpengaruh signifikan terhadap volatilitas return IHSG. Sama halnya dengan harga emas, dimana suku bunga tidak berpengaruh signifikan terhadap volatilitas return IHSG.

Keseluruhan variabel tersebut akan dianalisis untuk membuktikan dugaan bagaimana pengaruh antara nilai tukar rupiah, tingkat suku bunga SBI (BI rate) dan harga emas dunia terhadap Indeks LQ45. Hipotesis yang dibangun berisikan mengenai dugaan dari hubungan pada masing-masing variabel independen terhadap variabel dependen, yaitu:

H1: Nilai tukar rupiah berpengaruh negatif terhadap Indeks LQ45.

$\mathrm{H} 2$ : Tingkat suku bunga SBI (BI rate) berpengaruh negatif terhadap Indeks LQ45.

H3: Harga emas dunia berpengaruh negatif terhadap Indeks LQ45. 


\section{METODE PENELITIAN:}

Variabel dependen dalam penelitian ini adalah Indeks LQ45 yang terdaftar di Bursa Efek Indonesia. Indeks ini terdiri dari kumpulan saham yang memiliki likuiditas dan kapitalisasi pasar yang tinggi. Indeks LQ45 setiap 6 bulan sekali akan direvisi. Sedangkan variabel independennya adalah nilai tukar rupiah, tingkat suku bunga SBI (BI rate) dan harga emas dunia.

Data Indeks LQ45 dapat diperoleh di Pojok BEI FE UII. Kurs tengah nilai tukar rupiah terhadap dollar Amerika Serikat dimana datanya diambil dari laman resmi Bank Indonesia yaitu di www.bi.go.id., Tingkat suku bunga SBI (BI rate) yang datanya diperoleh dari laman resmi Bank Indonesia yaitu www.bi.go.id, Data harga emas yang digunakan adalah harga emas penutupan pada sore hari, data dapat diperoleh dari www.kitco.com. Keseluruhan data dalam bentuk harian kecuali BI rate dan rentang waktu pengamatan yang digunakan yaitu pada tahun 2011 sampai 2015. Dengan jenis data yang digunakan pada penelitian ini adalah data sekunder. Pengumpulan data didokumentasikan dari berbagai sumber kemudian dilakukan pencatatan dan pengkopian data. Sedangkan informasi lain diperoleh dari jurnal, makalah dan biku pustaka yang mendukung penelitian.

Populasi dalam penelitian ini adalah indeks harga saham dan faktor makro ekonomi. Sampel yang digunakan adalah Indeks LQ45 yang merupakan indeks harga saham terbaik di BEI, kurs tengah nilai tukar rupiah terhadap dollar AS, tingkat suku bunga SBI (BI rate) dan harga emas dunia berdasarkan London Gold Fixing dengan menggunakan harga penutupan. Sampel dalam bentuk data harian sebanyak kurang lebih 1168 hari pengamatan.

Metode analisis data yang pertama akan dilakukan uji asumsi klasik yang meliputi uji normalitas dengan menggunakan pengujian Grafik Histogram dan Normal P-P Plot Regression terhadap model yang diuji untuk melihat data terdistribusi normal atau tidak, kemudian uji autokorelasi dengan menggunakan uji Run Test dengan kriteria tanpa adanya autokorelasi jika signifikannya diatas 5\%, uji multikolinearitas dengan kriteria tolerance diatas $10 \%$ dan VIF dibawah 10 maka dapat diartikan bahwa model tidak terdapat korelasi antar variabel independen, dan yang terakhir adalah uji heterokesdastisitas dengan menggunakan scatterplot, jika scatterplot menyebar acak maka tidak terjadi heterokesdastisitas. Setelah itu dilakukan uji $\mathrm{t}$ untuk mengetahui ada atau 106 tidaknya pengaruh satu variabel independen terhadap variabel dependen, sementara satu atau lebih variabel independen lainnya dalam keadaan tetap atau dikontrol. Dan kemudian mengenai koefisien determinasi yang digunakan untuk mengukur kemampuan model dalam menerangkan variabel dependen. Nilai Kd berada dikisaran 0 sampai 1 . Yang digunakan adalah pada tabel Adjusted R Square.

\section{HASIL ANALISIS DAN PEMBAHASAN}

Pada bagian ini penulis akan menguraikan halhal yang berkaitan dengan pengolahan data dan pembahasan dari pengolahan data mengenai pengaruh nilai tukar rupiah, tingkat suku bunga SBI (BI rate) dan harga emas dunia terhadap Indeks LQ45. Sebelum dilakukannya uji regresi linear berganda, wajib bagi peneliti untuk melakukan uji asumsi klasik. Uji asumsi klasik yang pertama adalah uji normalitas.
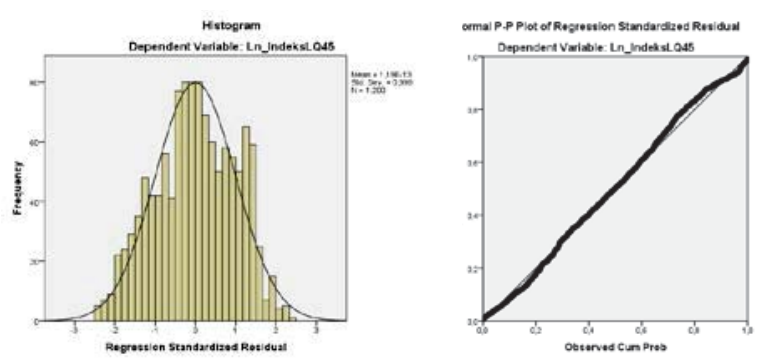

Gambar 1. Histogram and P-P Plot Regression Standardized Residual

Sumber: Data sekunder yang diolah dari BEI daily report, BI daily report dan LGF daily report periode tahun 2011-2015

Dapat dilihat pada histogram bahwa data berdistribusi normal dan pada Normal P-P Plot data berada disekitar garis diagonal dan mengikuti arah garis diagonal. Sehingga dapat diartikan bahwa data memenuhi asumsi klasik.

Uji berikutnya adalah uji autokorelasi dengan menggunakan uji Run Test.

Tabel 1. Uji Run Test

\begin{tabular}{cc}
\hline \multicolumn{2}{c}{ Runs Test } \\
\hline & Unstandardized \\
Asymp. Sig. (2-tailed) & Residual \\
&, 967 \\
\hline
\end{tabular}

Sumber: Data sekunder yang diolah dari BEI daily report, BI daily report dan LGF daily report periode tahun 2011-2015

Hasil menunjukkan bahwa nilai signifikansi berada pada angka 0,967 sehingga berada diatas taraf signifikannya yaitu 0,05 . 
Dengan demikian dapat diartikan bahwa residual bersifat acak dan tidak terjadi hubungan korelasi antar residual.

Kemudian uji multikolinearitas untuk mengetahui apakah terjadi korelasi antara variabel independen satu dengan yang lainnya atau tidak.

Tabel 2. Uji Multikolinearitas

\begin{tabular}{|c|c|c|c|c|c|c|c|c|}
\hline \multicolumn{9}{|c|}{ Coefficients $^{\mathrm{a}}$} \\
\hline & \multirow[t]{2}{*}{ Model } & \multicolumn{2}{|c|}{$\begin{array}{l}\text { Unstandardized } \\
\text { Coefficients }\end{array}$} & \multirow{2}{*}{$\begin{array}{c}\text { Standardized } \\
\text { Coefficients } \\
\text { Beta }\end{array}$} & \multirow[t]{2}{*}{$T$} & \multirow[t]{2}{*}{ Sig. } & \multicolumn{2}{|c|}{ Collinearity Statistics } \\
\hline & & $B$ & Std. Error & & & & Tolerance & VIF \\
\hline \multirow{4}{*}{1} & (Constant) & 069 &, 522 & &, 132 & 895 & & \\
\hline & In_KursTengah & 661 & ,031 &, 901 & 21,398 &, 000 & 223 & 1,179 \\
\hline & SQRT_Blrate & -892 & 279 & -115 & $-3,200$ &, 001 &, 309 & 3,233 \\
\hline & In_HargaEmas &, 089 &, 037 & ,115 & 2,412 & 016 & ,176 & 5,696 \\
\hline \multicolumn{9}{|c|}{ a. Dependent Variable: Ln_IndeksLQ45 } \\
\hline
\end{tabular}

Berdasarkan hasil perhitungan dapat dikatakan bahwa tidak terjadi multikolinearitas karena nilai dari tolerance setiap variabel berada diatas 10\% dan VIF berada dibawah 10 .

Uji terakhir yang dilakukan adalah uji heteroskesdastisitas dengan menggunakan grafik Scatterplot.

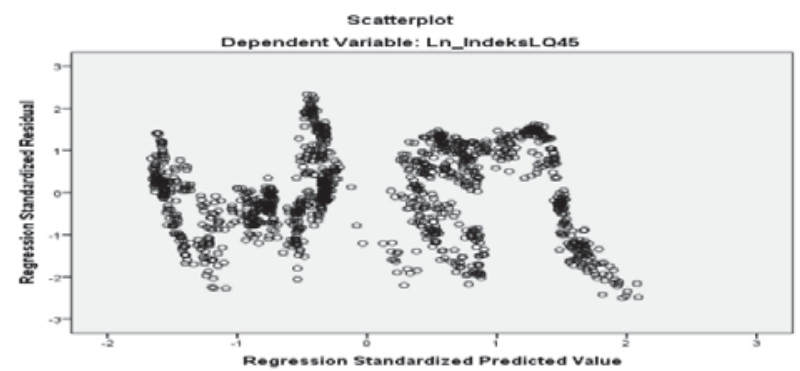

Gambar 2. Scatterplot

Sumber: Data sekunder yang diolah dari BEI daily report, BI daily report dan LGF daily report periode tahun 2011-2015

Dari grafik Scatter Plot terlihat hasil bahwa titik-titik (data pengamatan) menyebar secara acak dan tidak membentuk pola baik diatas nilai nol maupun dibawah nilai nol pada sumbu Y. Dengan demikian dapat diartikan bahwa tidak terjadi heterokesdastisitas pada model regresi.

Pengujian pengaruh secara parsial dimaksudkan untuk mengetahui ada atau tidaknya pengaruh satu variabel independen terhadap variabel dependen. Berdasarkan olah data dengan menggunakan SPSS 22, didapat hasil regresi adalah sebagai berikut :

Tabel 3. Nilai Uji $\mathrm{t}$

\begin{tabular}{|c|c|c|c|c|c|c|}
\hline \multicolumn{7}{|c|}{ Coefficients $^{\mathrm{a}}$} \\
\hline & \multirow[t]{2}{*}{ Model } & \multicolumn{2}{|c|}{$\begin{array}{l}\text { Unstandardized } \\
\text { Coefficients }\end{array}$} & \multirow{2}{*}{$\begin{array}{c}\begin{array}{c}\text { Standardized } \\
\text { Coefficients }\end{array} \\
\text { Beta } \\
\end{array}$} & \multirow[t]{2}{*}{$\begin{array}{ll}T \\
T\end{array}$} & \multirow[t]{2}{*}{ Sig. } \\
\hline & & B & Std. Error & & & \\
\hline \multirow{4}{*}{1} & (Constant) &, 069 &, 522 & & ,132 &, 895 \\
\hline & Ln_KursTengah &, 664 &, 031 &, 904 & 21,398 &, 000 \\
\hline & SQRT_Blrate &,- 892 &, 279 &,- 115 & $-3,200$ &, 001 \\
\hline & Ln_HargaEmas & ,089 &, 037 & ,115 & 2,412 &, 016 \\
\hline \multicolumn{7}{|c|}{ a. Dependent Variable: Ln_IndeksLQ45 } \\
\hline & $\begin{array}{l}\text { r: Data sel } \\
\text { report d }\end{array}$ & iolah & $\begin{array}{l}\text { dari BEI } \\
\text { periode } t\end{array}$ & $\begin{array}{l}\text { daily repor } \\
\text { tahun } 2011 \text { - }\end{array}$ & 2015 & \\
\hline
\end{tabular}

Uji yang dilakukan adalah dengan melibatkan variabel independen yaitu nilai tukar rupiah, tingkat suku bunga SBI (BI rate) dan harga emas dunia serta variabel dependennya adalah Indeks LQ45. Persamaan regresi linear berganda dari hasil output tersebut adalah sebagai berikut :

$$
\begin{gathered}
\text { LQ45 }=0,069+0,664 \text { KURS }-0,892 \text { BI }+0,089 \\
\text { EMAS }+e
\end{gathered}
$$

Nilai tukar rupiah memiliki koefisien regresi sebesar 0,664 dengan nilai signifikansi yaitu 0,000 . Dapat diartikan bahwa variabel nilai tukar rupiah berpengaruh secara positif dan signifikan terhadap Indeks LQ45. Pengaruh yang positif memberikan petunjuk bahwa apabila nilai tukar rupiah mengalami depresiasi atau pelemahan terhadap dollar Amerika Serikat maka dapat menguatkan Indeks LQ45. Hal ini dikarenakan Indeks LQ45 didominasi oleh saham yang berorientasi ekspor. Produk utama ekspor Indonesia yaitu industri tekstil dan produk tekstil, karet dan produk karet, sawit, produk hasil hutan, elektronik, alas kaki, kopi, otomotif, udang dan kakao (www.komoditi.co.id). Indonesia juga mengekspor barang hasil produksi lain seperti barang konsumsi, semen, hasil tambang, dll. Dengan demikian, ketika nilai tukar rupiah mengalami pelemahan, emitenemiten saham tersebut akan mendapat dampak yang positif. Pasar luar negeri akan menganggap harga barang murah, sehingga permintaan meningkat. Emiten yang terkena dampak positif akan meningkat harga sahamnya yang kemudian berdampak pada peningkatan indeks harga saham. Dapat diambil contoh terjadi kenaikan nilai tukar rupiah terhadap dollar yaitu pada tanggal 29 Juli 2015 dengan nilai tukar Rp 13.444 naik menjadi Rp 13.468 pada tanggal 30 
Juli 2015, dapat diartikan bahwa pada saat itu nilai tukar rupiah terdepresiasi. Kemudian, ketika nilai tukar rupiah ditutup melemah pada tanggal 30 Juli 2015, dihari berikutnya, investor merespon positif sehingga pada saham-saham yang terdaftar di Indeks LQ45 yang berorientasi pada ekspor mengalami kenaikan. Contohnya, saham LSIP (PT PP London Sumatera Indonesia, Tbk) yang merupakan eksportir CPO atau sawit ke beberapa negara seperti Amerika Serikat, India, China dan Eropa (www.koran.bisnis.com) mengalami penguatan dari harga $\mathrm{Rp} 1.320$ pada tanggal 30 Juli 2015 menjadi Rp 1.355 pada tanggal 31 Juli 2015. Saham ASII ( PT Astra Internasional Tbk.) yang menggenjot ekspor otomotif dan onderdil ke beberapa negara (investasi.kontan.co.id) mengalami kenaikan saham dari Rp 6.575 menjadi Rp 6.650. Penguatan harga saham juga terjadi bagi emiten saham pengekspor barang konsumsi (Consumer Goods) yaitu PT Unilever Indonesia Tbk (UNVR) yang mengekspor produknya ke 21 negara termasuk Belanda, United Kindom (UK) dan beberapa negara di kawasan Amerika (www.economy.okezone.com). Saham UNVR mengalami penguatan yaitu dari harga $\mathrm{Rp} 38.500$ menjadi Rp 40.000. Dari kenaikan harga saham pada emiten-emiten saham yang berorientasi pada ekspor tersebut, menyebabkan kenaikan Indeks LQ45 yaitu pada tanggal 30 Juli 2015 pada level 793,252 naik menjadi level 813,097 pada tanggal 31 Juli 2015. Hasil penelitian ini mendukung penelitian yang dilakukan Surbakti (2016).

Tingkat suku bunga SBI (BI rate) memiliki koefisien regresi sebesar -0,892 dengan tingkat signifikansi 0,001 . Hal ini dapat diartikan bahwa variabel tingkat suku bunga SBI (BI rate) memiliki pengaruh yang negatif dan signifikan terhadap Indeks LQ45. Hasil dari pengolahan data ini sesuai dengan hipotesis yang dibangun oleh penulis. Dengan demikian, tingkat suku bunga SBI (BI rate) masih dijadikan acuan sebelum berinvestasi dipasar modal.

Harga emas dunia memiliki koefisien regresi sebesar 0,089 dengan nilai signifikansi yaitu 0,016 . Dapat diartikan variabel harga emas dunia berpengaruh secara positif dan signifikan terhadap Indeks LQ45. Pengaruh positif dan signifikan yang diperoleh tidak sejalan dengan hipotesis yang dibangun. Pengaruh yang positif dan signifikan dapat diartikan bahwa kenaikan harga emas dunia dapat berpengaruh terhadap meningkatnya Indeks LQ45. Dengan demikian, pada saat ini, masyarakat tidak lagi menjadikan 108 emas sebagai alternatif investasi selain saham, tetapi menjadikan emas sebagai lindung nilai dari investasi saham dan memasukkan dalam satu portofolio investasi dengan tujuan untuk mengurangi risiko yang dihadapi. Sehingga kenaikan harga emas dunia berpengaruh pada naiknya Indeks LQ45. Penelitian ini mendukung peneliti sebelumnya yaitu Nordin (2014) .

Koefisien determinasi memberikan hasil bahwa ketiga variabel independen tersebut dapat menjelaskan variabel dependen yaitu Indeks LQ45 sebesar 52,2\% sedangkan 47,8\% dijelaskan oleh variabel independen lain diluar model.

\section{KESIMPULAN DAN SARAN}

Dapat diambil kesimpulan dari hasil penelitian yang dilakukan yaitu nilai tukar rupiah berpengaruh positif dan signifikan terhadap Indeks LQ45. Pengaruh yang positif memberikan petunjuk bahwa apabila nilai tukar rupiah terdepresiasi maka dapat menguatkan Indeks LQ45. Pengaruh ini disebabkan karena Indeks LQ45 didominasi oleh saham yang berorientasi pada ekspor. Barang ekspor menjadi murah menurut penilaian luar negeri, permintaan meningkat dan dapat meningkatkan indeks harga saham. Tingkat suku bunga SBI (BI rate) berpengaruh negatif dan signifikan terhadap Indeks LQ45. Sehingga menunjukkan bahwa tingkat suku bunga SBI (BI rate) masih dijadikan acuan sebelum berinvestasi dipasar modal. Harga emas dunia berpengaruh positif dan signifikan terhadap Indeks LQ45. Pada saat ini, masyarakat bukan lagi menjadikan emas sebagai alternatif investasi dari saham. Sebagian masyarakat menjadikan emas sebagai lindung nilai dari saham yaitu dengan memasukkan keduanya dalam satu portofolio investasi dengan tujuan untuk mengurangi risiko yang dihadapi. Sehingga kenaikan harga emas dunia berpengaruh pada naiknya Indeks LQ45

Saran yang dapat diberikan dari peneliti bagi investor adalah untuk lebih memperhatikan faktor makro ekonomi seperti nilai tukar, suku bunga, harga emas dunia dan faktor makro ekonomi yang lainnya sebelum berinvestasi dipasar modal, baik untuk investasi jangka pendek maupun jangka panjang. Karena sudah terbukti bahwa faktor makro ekonomi dapat mempengaruhi harga saham dan indeks dimana saham itu terdaftar. Bagi penelitian selanjutnya, diharapkan untuk menambah variabel makro ekonomi yang lebih bervariasi dengan data 
pengamatan harian karena lebih menggambarkan kondisi pasar pada saat pengamatan.

\section{REFERENSI}

Bhunia, A., \& Sanji, P. (2014). Investigating the Impact of Gold Price and Exchange Rates on Sensex: an Evidence India. Dalam European Journal of Accounting, Finance and Business, Vol.2

Hafiyyan. (2016). Menguak Potensi Kenaikan Saham LSIP. http://koran.bisnis.com/read/20161017/4 42/593051/menguak-potensi-kenaikansaham-lsip. Diakses pada 21 Januari 2017.

Hasniawati, A. P. (2014). Grup Astra Genjot Ekspor Otomotif. Http://investasi.kontan.co.id/news/grupastra-genjot-ekspor-otomotif. Diakses pada 21 Januari 2017

Langi, T. M. (2014). Analisis Pengaruh Suku Bunga Bank Indonesia, Jumlah Uang Beredar dan Tingkat Kurs terhadap Tingkat Inflasi di Indonesia. Jurnal Berkala Ilmiah Efisiensi, 14(2)

Madura, J. (2006). International Corporate Finance, Keuangan Perusahaan Internasional. Jakarta: Salemba Empat

Mojazeb, M., \& Shakerian, M. S. (2014). The Effects of Gold Price and Oil Price on Stock Returns of The Bank in Iran. Arabian Journal of Bussiness and Management Review (OMAN Chapter), 3(9)

Nordin, M., Sabariah, N., and Rusmawati, I. (2014). The Impact of Commodity Price, Interest Rate and Exchange Rate on Stock Market Performance : An Emphiritical Analysis from Malaysia. Malaysian Management Journal, Vol.18, 39-52

Purnomo, T. H (2013). Pengaruh Nilai Tukar, Suku Bunga dan Inflasi Terhadap dan Inflasi terhadap Return Saham Pada Perusahaan Property. Jurnal Ilmu \& Riset Manajemen, 2(10)

Samsul, M. (2006). Pasar Modal dan Manajemen Portofolio. Jakarta: Erlangga.

Simanjuntak, U. (2016). Komoditas Unggulan dari Ekspor Dari Indonesia. Http://komoditi.co.id/komoditiunggulan-indonesia/. Diakses pada 19 Januari 2017
Sudirman, I.. (2011). Kebijakan Fiskal dan Moneter. Denpasar: Kencana Prenada Media Group

Surbakti, E.H., Noer A. A., \& Tubagus, N. A. M (2016). The Impact of Macroeconomic Variables on JCI's Stock Return Volatility in Pre and Post Global Economic Crisis. Dalam International Journal of Scientific and Research Publications, Vol. 6

Windarto. (2013). Unilever Terus Tambah Negara Tujuan Ekspor. Http://economy.okezone.com/read/2013/ 01/31/unilever-terus-tambah-negaratujuan-ekspor. Diakses pada 21 Januari 2017

www.bi.go.id. Diakses pada tanggal 20 April 2016

www.idx.co.id. Diakses pada tanggal 23 April 2016

www.kitco.com. Diakses pada tanggal 20 April 2016 
Jurnal Manajemen Maranatha 『 Vol. 17 Nomor 2, Mei (2018) 